\title{
Review of the Maluku Islands species of the lanternfly genus Birdantis Stål, 1863, with a new species and identification key (Hemiptera: Fulgoromorpha: Fulgoridae)
}

\author{
Jérôme CONSTANT \\ Royal Belgian Institute of Natural Sciences, O.D. Phylogeny and Taxonomy, Entomology, \\ Vautier Street 29, B-1000 Brussels, Belgium. \\ Corresponding author: jerome.constant@naturalsciences.be
}

urn:1sid:zoobank.org:author:6E6072A1-9415-4C8D-8E60-2504444DB290

\begin{abstract}
A new species of the genus Birdantis Stål, 1863 (Hemiptera: Fulgoridae), B. bhaskarai sp. nov. from Larat Island (Tanimbar), is described. Birdantis collaris (Walker, 1870) stat. rev. and B. trilineata (Schmidt, 1926) stat. rev. are reinstated as valid species, respectively from status of subspecies and as junior synonym of $B$. delibuta Stål, 1863 . These four species, as well as the other one previously described from the Maluku Islands, $B$. decens Stål, 1863, are illustrated from their type specimens. An identification key, a distribution map, illustrations of habitus and details of male genitalia are provided. The synonymy between Myrilla Distant, 1888 and Birdantis is formally reinstated and all species formerly placed in the subgenus Birdantis (Myrilla) are transferred to Birdantis sensu stricto. Birdantis is transferred to the subfamily Aphaeninae Blanchard, 1847 and now contains eighteen species distributed in Maluku (five species), New Guinea and neighbouring islands (ten species) and Australia (three species).
\end{abstract}

Keywords. Wallacea, Indonesia, planthopper, lanternbug, biodiversity.

Constant J. 2018. Review of the Maluku Islands species of the lanternfly genus Birdantis Stål, 1863, with a new species and identification key (Hemiptera: Fulgoromorpha: Fulgoridae). European Journal of Taxonomy 461: 1-20. https:/doi.org/10.5852/ejt.2018.461

\section{Introduction}

The family Fulgoridae counts 143 genera and 762 species, distributed mainly in the tropical and subtropical regions of the world, with some taxa extending to temperate regions. The family contains some of the most spectacular insects, such as the New World 'peanut bug' (Fulgora spp.) surrounded by several legends or the species of the genus Pyrops Spinola, 1839 in the Oriental Region, which are recognized at first glance by all entomologists (O'Brien 2002). Trophobiotic interactions with other insects (Formicidae, Blattodea, Lepidoptera), geckos (Reptilia: Squamata: Gekkonidae) and even snails (Mollusca: Gasteropoda) have been reported in recent years for several species both from the Old and New World (Naskrecki \& Nishida 2007; Constant 2015).

The fauna of Fulgoridae in the Maluku Islands is very poor, with only two genera and six species, compared to the fauna of Sulawesi and adjacent islands to the west (5 genera and 30 species) or that 
of New Guinea (9 genera and 37 species) to the east. Both genera recorded from the Maluku Islands, Birdantis Stål, 1863 and Hariola Stål, 1863, are also present in New Guinea, but all Malukan species are endemic in the archipelago (Bourgoin 2018). The Maluku Islands lie in Wallacea, the region marking the transition between the Asian and Australian biogeographical blocks, are geologically relatively young (1-15 million years old) and were never attached to larger landmasses. As they lie between the Weber's and Lydekker's lines, their fauna shows greater affinities with Australasia than with Asia as well as a high degree of endemism. The islands are small in size and mountainous, and are covered in rain forest except the Tanimbar Islands and other southeastern islands, which are arid and sparsely vegetated (Monk et al. 1997).

The genus Birdantis comprises fifteen species distributed in New Guinea, the Maluku Islands and Australia (Cape York Peninsula) (Bourgoin 2018). The description of the first two species of Birdantis from the Maluku Archipelago dates from more than 150 years ago, when Stål (1863) described the genus to accommodate $B$. decens Stål, 1863 and $B$. delibuta Stål, 1863. Two additional Malukan species were described, one in the genus Polydictya, P. collaris Walker, 1870, and one in the genus Myrilla, M. trilineata Schmidt, 1926. The latter species were considered as a synonym (trilineata) and a variety (collaris) of $B$. delibuta, respectively, leaving two valid species of Birdantis for the Maluku Islands: B. decens and B. delibuta (Lallemand 1963; Nagai \& Porion 1996).

The study of recent material of Fulgoridae in the collections of the Royal Belgian Institute of Natural Sciences revealed one new species of Birdantis from Larat Island near Tanimbar and led to a critical review of the type material of all species described from the Maluku Islands.

The present paper aims to propose a new subfamily placement of Birdantis, to update the status of the genus, to review the status of all species known from the Maluku Archipelago, to describe the new species from Larat Island and to propose an illustrated identification key to the species of the treated area.

\section{Material and methods}

The male genitalia were dissected as follows: the pygofer was cut from the abdomen of the softened specimen with a needle blade, then boiled for some minutes in a $10 \%$ solution of potassium hydroxide $(\mathrm{KOH})$. The aedeagus was dissected with a needle blade and all pieces examined in ethanol, the whole preparation placed in glycerine for preservation. Observations were done with a Leica MZ8 stereo microscope. Photographs of specimens were taken with a Canon EOS 700 D camera with a Sigma DG Macro lens and of genitalia with a Leica EZ4W stereo microscope with an integrated camera, stacked with CombineZ software and optimized with Adobe Photoshop CS3. The metatibiotarsal formula gives the number of spines on (side of metatibia) apex of metatibia/apex of first metatarsus/apex of second metatarsus. The terminology for the venation follows Bourgoin et al. (2015).

For the transcription of the labels of the types, the wording on each single label is delimited by square brackets. My personal comments in the synonym lists of the species are followed by "!".

The distribution map was produced with SimpleMappr (Shorthouse 2010).

The measurements were taken as in Constant (2004) and the following acronyms are used:

$\mathrm{BF}=$ maximum breadth of the frons

$\mathrm{BTg}=$ maximum breadth of the tegmen

$\mathrm{BV}=$ maximum breadth of the vertex

$\mathrm{LF}=$ length of the frons in median line

LT = total length (apex of head to apex of tegmina)

$\mathrm{LTg}=$ maximum length of the tegmen

$\mathrm{LV}=$ length of the vertex in median line 
Acronyms used for the collections:

BMNH $=$ Natural History Museum, London, UK

$\mathrm{EBC}=$ Edy Bhaskara collection, Indonesia

NHRS $=$ Naturhistoriska Riksmuseet, Stockholm, Sweden

RBINS = Royal Belgian Institute of Natural Sciences, Brussels, Belgium

ZMPA = Polish Academy of Sciences, Museum of the Institute of Zoology, Warsaw, Poland

\section{Results}

Class Hexapoda Blainville, 1816

Order Hemiptera Linnaeus, 1758

Suborder Auchenorrhyncha Duméril, 1806

Infraorder Fulgoromorpha Evans, 1946

Superfamily Fulgoroidea Latreille, 1807

Family Fulgoridae Spinola, 1839

Subfamily Aphaeninae Blanchard, 1847

Genus Birdantis Stål, 1863

Birdantis Stål, 1863: 581 (described, compared with Aphaena Guérin-Méneville, 1834; type species: Birdantis decens Stål, 1863 by subsequent designation in Distant 1906: 26).

Myrilla Distant, 1888: 487 (described, compared with Polydictya Guérin-Méneville, 1844; type species: Myrilla obscura Distant, 1888, by monotypy). syn. rev.

\section{Remarks}

Lallemand (1959) synonymized Myrilla under Birdantis and proposed a key to the species of Birdantis. However, Fennah (1977) considered Myrilla as a subgenus of Birdantis, separating them on characters of the vertex, i.e., anterior margin of vertex straight, without deep transverse sulcus behind it in Myrilla; anterior margin of vertex concave, with a deep transverse sulcus behind it in Birdantis s. str. It is therefore currently formally divided into two subgenera: Birdantis (ten species and one subspecies) and Myrilla (two species) (Fennah 1977; Nagai \& Porion 1996). The genus is externally close to the Oriental Polydictya Guérin-Méneville, 1844 and Gebenna Stål, 1863, and the Australian Desudaboides Musgrave, 1927 (Lallemand 1963; Nagai \& Porion 1996; Constant 2010, 2011). Nagai \& Porion (1996) followed the classification in Fennah (1977), but in my paper on the species of Birdantis from Australia (Constant 2011), I questioned the value of the subgenera as defined by Fennah (1977), because intermediate species exist, and followed the views of Lallemand (1959) but without formally reinstating the synonymy between Birdantis and Myrilla. Accordingly, three species remained without subgeneric affiliation (Bourgoin 2018) within the last formally accepted classification of Fennah (1977).

The genus Birdantis is currently placed in the Poiocerina Haupt, 1929 of the Poiocerini Haupt, 1929, in the subfamily Poiocerinae Haupt, 1929 (Lallemand 1963; Constant 2011; Bourgoin 2018). However, Urban \& Cryan (2009) have shown, based on molecular data, that Fulgoridae can be separated into two main clades, one grouping all New World taxa with strong support, the other containing all Old World taxa. Hence, as the type genus of the Poiocerinae is the Neotropical genus Poiocera Laporte, 1832, the suprageneric placement of Birdantis needs to be reconsidered.

The classifications proposed by Metcalf (1947), Lallemand (1963) and Nagai \& Porion (1996) were based on a very small number of characters of the head, especially the presence/absence and shape of the cephalic process. The genus Birdantis is here transferred to the subfamily Aphaeninae, following 
the conclusions of the DNA study by Urban \& Cryan (2009), which place the genus close to Desudaba Walker, 1858. However, the latter study did not contain any species of the genera Polydictya, Gebenna or Desudaboides, which are putatively considered closely related to Birdantis based on morphological characters. Hence, an accurate tribal placement requires a complete study of the suprageneric relations between the genera of Aphaeninae with the inclusion of more Old World taxa in the molecular analysis and the integration of morphological data (Urban \& Cryan 2009).

\section{Species included}

Birdantis bernhardi Lallemand, 1959 - New Guinea

Birdantis bhaskarai sp. nov. - Larat Island

Birdantis bloetei Lallemand, 1959 - New Guinea

Birdantis collaris (Walker, 1870) - Morotai Island

Birdantis decens Stål, 1863 - Aru Island

Birdantis delibuta Stål, 1863 - Ternate Island

Birdantis dorsinigra Lallemand, 1959 - New Guinea

Birdantis enyo Fennah, 1977 - New Guinea

Birdantis goemansi Constant, 2011 - Australia (N Queensland)

Birdantis hesperugo Fennah, 1977 - New Guinea

Birdantis lineatifrons (Schmidt, 1907) - New Guinea

Birdantis mouldsi Constant, 2011 - Australia (N Queensland)

Birdantis obscura (Distant, 1888) - New Guinea

Birdantis papuana (Distant, 1906) - New Guinea

Birdantis semihyalina (Distant, 1906) - New Guinea

Birdantis similis (Schmidt, 1911) - New Guinea

Birdantis trilineata (Schmidt, 1926) - Ambon, Boano, Buru and Seram Islands

Birdantis virginiae Constant, 2011 - Australia (N Queensland)

\section{Identification key to the species of Birdantis of the Maluku Archipelago}

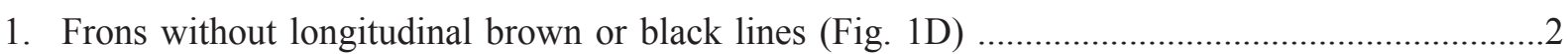

- Frons with longitudinal brown or black lines (Fig. 6D) …...................................................

2. Abdomen mostly orange dorsally (Fig. 1A); bulge between vertex and frons pale yellow-brown (Fig. 1B)

Birdantis bhaskarai sp. nov.

- Abdomen mostly black dorsally (Fig. 4A); bulge between vertex and frons black (Fig. 4C) ...... Birdantis collaris (Walker, 1870)

3. Frons with five longitudinal black stripes, the three central ones merging into a transverse line along dorsal margin of frons (Fig. 5F); apical half of tegmina hyaline (Fig. 5A)

Birdantis decens Stål, 1863

- Frons with three longitudinal black stripes limited to about the ventral half of frons (Fig. 8D); apical half of tegmina infuscate (Fig. 8A)

4. Anterior margin of frons strongly roundly protruding in dorsal view, the visible portion of frons slightly longer than vertex in median line (Fig. 8B); median carina of pronotum acute (Fig. 8B); posterior wings with basal reddish brown marking (Fig. 8A) .... Birdantis trilineata (Schmidt, 1926)

- Anterior margin of frons convex in dorsal view, the visible portion of frons about $2 / 3$ as long as vertex in median line (Fig. 6C); median carina of pronotum slightly marked (Fig. 6C); posterior wings with basal red marking (Fig. 6A)

Birdantis delibuta Stål, 1863 


\section{Birdantis bhaskarai sp. nov. urn:1sid:zoobank.org:act:3424BD5B-34C2-4516-A0CB-9415F485F537}

Figs $1-3$

\section{Diagnosis}

This species can be separated from all other species of Birdantis by the following combination of characters:

(1) frons entirely yellow-brown without lines or spots (Fig. 1D)

(2) bulge between frons and vertex coloured as vertex (Fig. 1B)

(3) abdomen mostly orange dorsally (Fig. 1A) and ventrally (Fig. 1C)

(4) tegmina opaque on basal half and infuscate on distal half (Fig. 1A)

(5) hind wings largely smoky, but not hyaline or with a large black area (Fig. 1A)

\section{Etymology}

This species is dedicated to Mr Edy Bhaskara (Indonesia) in acknowledgment of his generous contribution to the present work.

\section{Material examined}

Holotype

INDONESIA: $\widehat{\partial}$ (dissected, Figs 1-2), Larat Island, $7^{\circ} 09^{\prime} 17^{\prime \prime} \mathrm{S}, 131^{\circ} 54^{\prime} 48^{\prime \prime}$ E [Coll. I.R.Sc.N.B., Indonesia, Tanimbar islands, Larat Island, xii.2016, Gift from E. Bhaskara, I.G.: 33.453] (RBINS).

\section{Paratypes}

INDONESIA: $1 \hat{\jmath}, 4$ 우, same collection data as for holotype (RBINS).

\section{Other material}

INDONESIA: 2 우, same collection data as for holotype (EBC).

\section{Description}

MeAsurements and Ratios. LT: $\widehat{o}(\mathrm{n}=2): 19.0 \mathrm{~mm}(18.9-19.2)$; $q(\mathrm{n}=6): 21 \mathrm{~mm}(20.4-21.2)$. $\mathrm{LTg} / \mathrm{BTg}=3.45 ; \mathrm{BV} / \mathrm{LV}=4.45 ; \mathrm{LF} / \mathrm{BF}=0.83$.

HeAd (Fig. 1B, D, F). Pale yellow-brown with small black marking at posterior angles of vertex, a larger black marking behind eyes, median portion of clypeus darker and more reddish, with a yellowish central line, labium pale yellow-brown turning to brown on two apical segments and antennae brown. Vertex with deep transverse groove and all margins carinate, shorter in middle than on sides. Frons finely wrinkled, with two smooth longitudinal carinae slightly diverging towards dorsum and a slight longitudinal groove on each side between carina and lateral margin; broadest near base, above clypeus; convex in dorsal view and with dorsal margin rounded in perpendicular view; bulge between frons and vertex only visible dorsally. Ocelli under eyes. Antennae with scape short and cylindrical, and pedicel inflated and reniform. Clypeus narrower than frons, reaching apex of procoxae. Labium with penultimate segment surpassing hind coxae (Fig. 1C).

Thorax (Fig. 1B, D, F). Pronotum pale yellow-brown, with median carina and impressed point on each side of latter; small back-brown spot on each side of disc, short black-brown line on median carina on anterior half and brown marking behind eye. Mesonotum dark brown, with median and peridiscal carinae well marked, concolorous; wrinkled in the area limited by peridiscal carinae; mesothoracic sternites pale yellow-brown. Metathoracic sternites dark brown. Tegulae yellow-brown. 

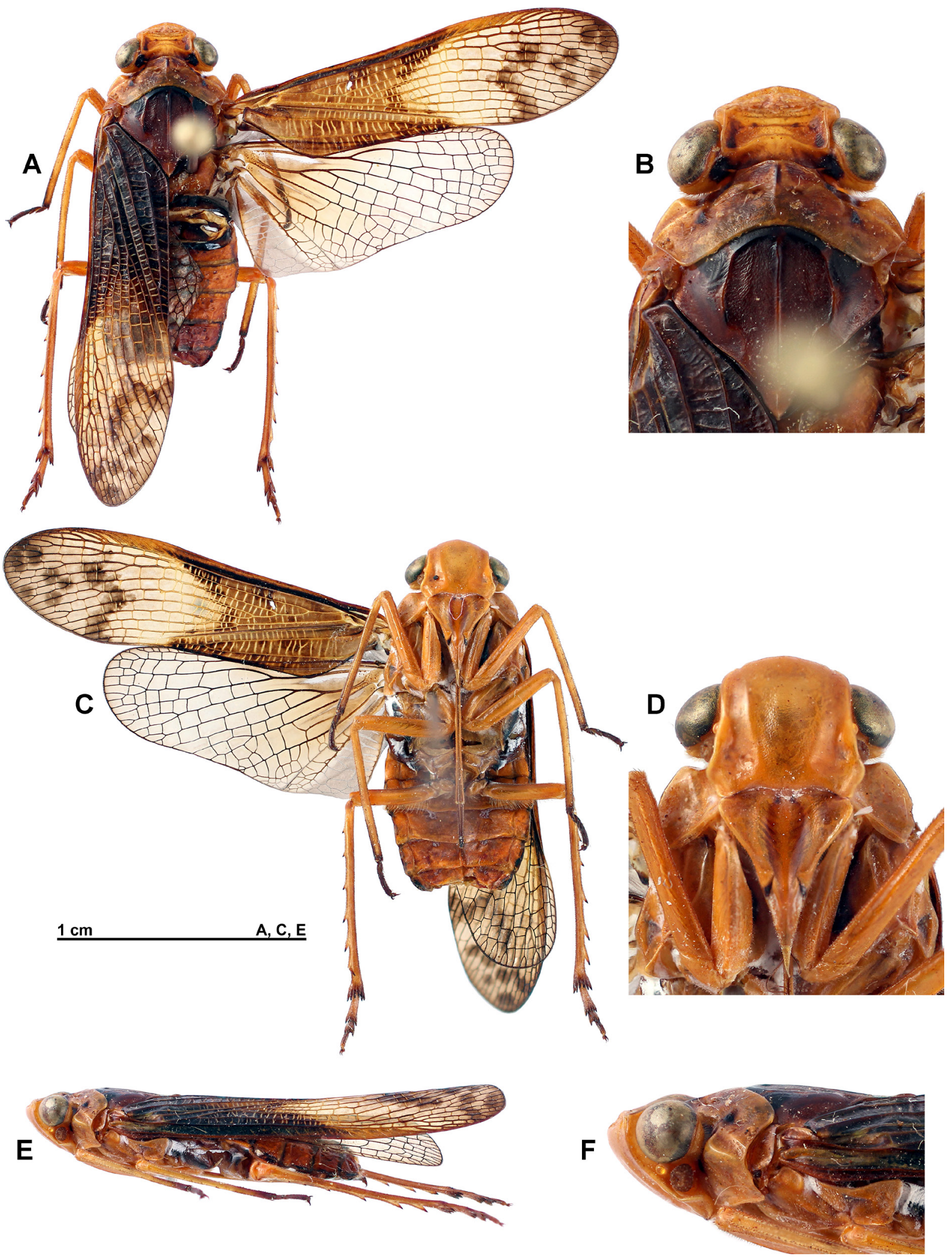

Fig. 1. Birdantis bhaskarai sp. nov., holotype, ô. A. Habitus, dorsal view. B. Head and thorax, dorsal view. C. Habitus, ventral view. D. Head, normal view of frons. E. Habitus, lateral view. F. Head and thorax, lateral view. B, D, F not to scale. 


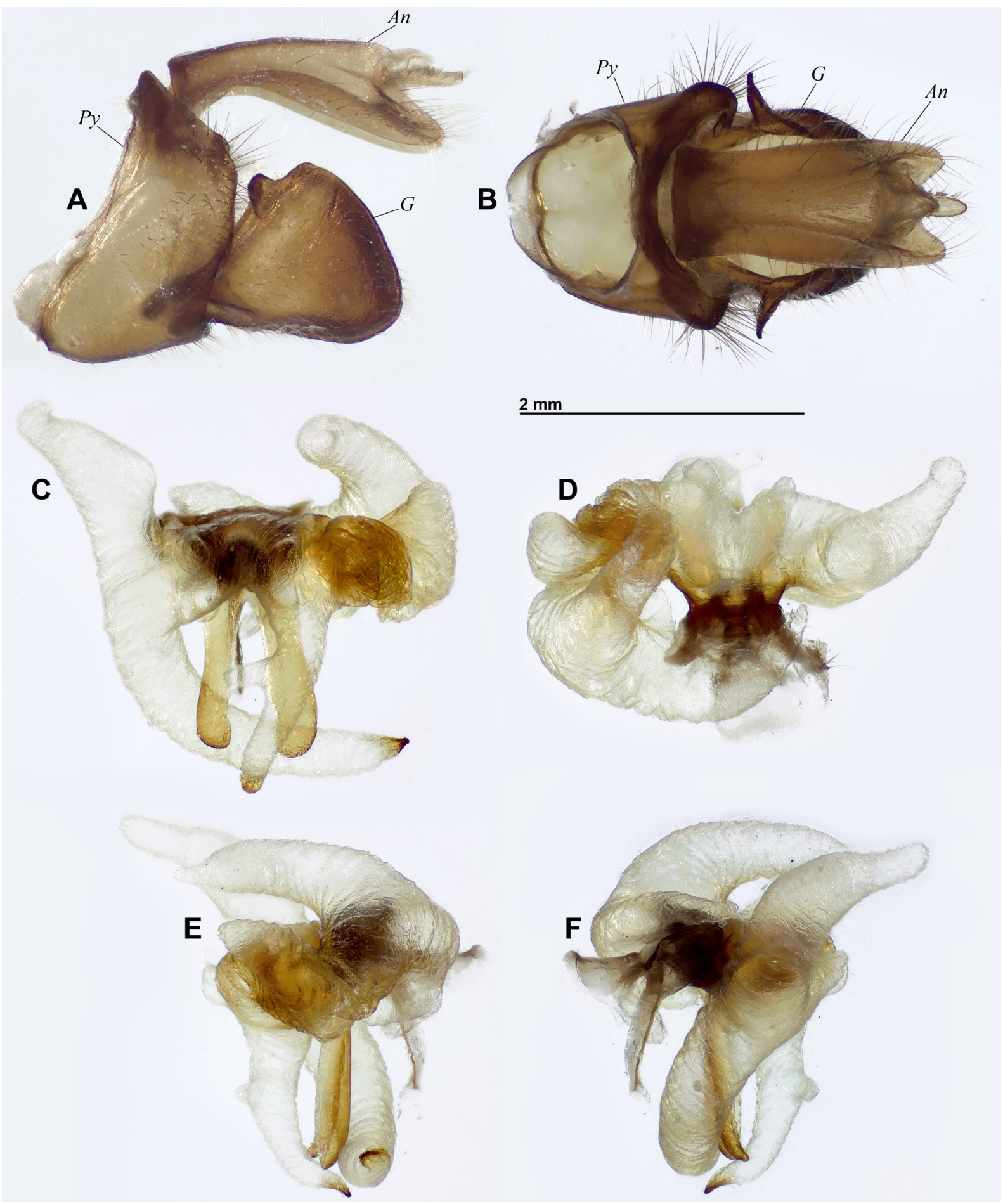

Fig. 2. Birdantis bhaskarai sp. nov., holotype, $\widehat{\jmath}$, genitalia. A. Pygofer, anal tube and gonostyli, left lateral view. B. Pygofer, anal tube and gonostyli, dorsal view. C. Aedeagus, posterior view. D. Aedeagus, dorsal view. E. Aedeagus, right lateral view. F. Aedeagus, left lateral view. Abbreviations: $A n=$ anal tube; $G=$ gonostyli; $P y=$ pygofer. 


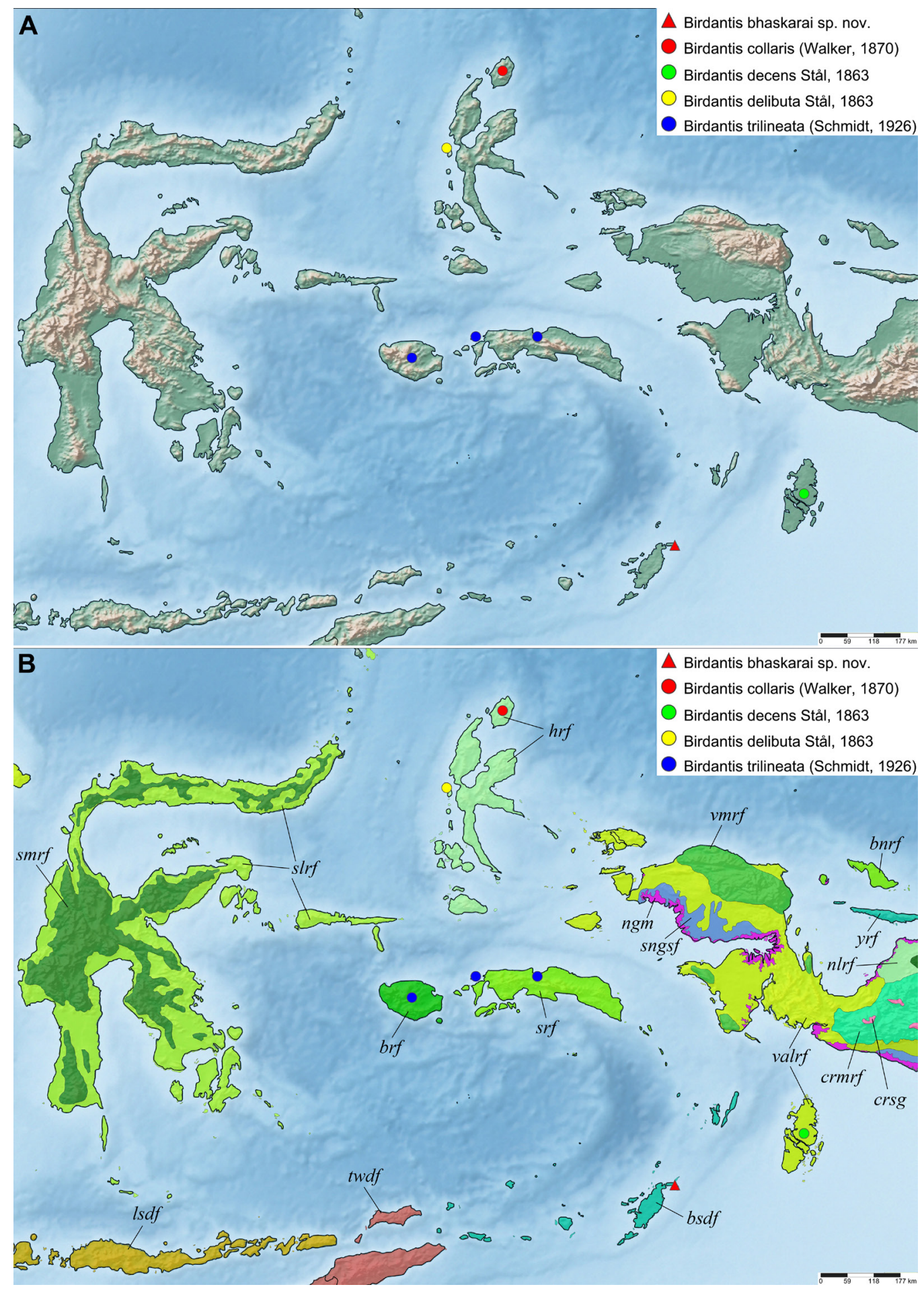

Fig. 3. Birdantis spp. from Maluku, distribution map. A. Topographic map. B. Ecoregions map. Abbreviations: $b n r f=$ Biak-Numfoor rain forests; $b r f=$ Buru rain forests; $b s d f=$ Banda Sea Islands moist deciduous forests; $c r m r f=$ Central Range montane rain forests; $c r s g=$ Central Range subalpine grasslands; $h r f=$ Halmahera rain forests; $l s d f=$ Lesser Sundas deciduous forests; $n g m=$ New Guinea mangroves; $n l r f=$ Northern New Guinea lowland rain forests; $\operatorname{slrf}=$ Sulawesi lowland rainforests; $s m r f=$ Sulawesi montane rainforests; sngsf $=$ Southern New Guinea freshwater swamp forests; $s r f=$ Seram rain forests; $t w d f=$ Timor and Wetar deciduous forests; valrf = Vogelkop-Aru lowland rain forests; $v m r f=$ Vogelkop montane rain forests; $y r f=$ Yapen rain forests. 
Tegmina (Fig. 1A, C). Elongate, broader at nodal line and acutely rounded apically. Corium and clavus with numerous cross-veins, brown variegated with darker patches and a blackish line along external side of vein $\mathrm{Pc}+\mathrm{CP}$; veins and cross-veins yellow. Membrane smoky, roundly extending inside corium medially and with brown spots on distal part and brown markings on nodal line; veins yellow turning to black-brown after nodal line.

HiND WINGS (Fig. 1A, C). Light smoky brown with veins black-brown, darker at basal angle and with anal area with a grey hue and cross-veins whitish; maximal breadth near base; slightly broader than tegmina.

Legs (Fig. 1A, C). Elongate and slender. Pale yellow-brown with apex of pro- and mesofemora black distally; pro- and mesotarsi black; metatibiae brown apically, with six lateral spines and six apical spines, all spines dark brown apically; metatarsi with first tarsomere yellow-brown, brown apically and with nine apical spines ventrally, second and third tarsomeres dark brown, the second one with eight apical spines ventrally. Metatibiotarsal formula: (6) 6/9/8.

\section{Male genitalia}

Pygofer higher than long, about 1.4 times as high as maximum length, longer ventrally and abruptly narrowing on dorsal $1 / 4$ in lateral view; dorsal margin of pygofer oblique in lateral view (Fig. 2A). Anal tube elongate, about 2.1 times as long as maximum breadth, curved ventrally near base; lateral margins subparallel, only slightly sinuate and with narrowest portion at basal $1 / 4$; apical margin strongly emarginate in dorsal view, acutely rounded in lateral view (Fig. 2A-B). Gonostyli subtriangular in lateral view, with posterior margin rounded; anterodorsal margin emarginate after lateral process; lateral process laminate, directed laterally and apically pointed, with apical point directed lateroventrally (Fig. 2A-B). Aedeagus mostly membranous; phallobase with two ventral, elongate processes; aedeagus s. str. strongly reduced but endosoma well developed with six membranous digitiform processes, with posteroventral left process with secondary process directed centrally (Fig. 2C-F).

\section{Distribution}

Larat Island (Fig. 3).

Birdantis collaris (Walker, 1870) stat. rev.

Figs 3-4

Polydictya collaris Walker, 1870: 98 (described).

Polydictya collaris - Gerstaecker 1895: 27 (doubt on generic placement in Polydictya).

Birdantis collaris - Breddin 1900: 193 (transferred to Birdantis; recorded from Halmahera Island: Soah Konorah). — Distant 1906: 26 (listed; = vittiventris Walker in litt. (error!)). — Metcalf 1947: 91 (catalogued).

non Birdantis delibuta f. collaris - Lallemand 1959: 196 (keyed; treated as a local form of B. delibuta (error!)); 1963: 12 (same as preceding reference).

non Birdantis delibuta collaris - Fennah 1977: 376 (keyed), 377 (recorded from Ambon Island (error!); treated as a subspecies of B. delibuta (error!); male genitalia illustrated (error!)). — Nagai \& Porion 1996: 14 (listed; = vittiventris Walker in litt. (error!)).

\section{Note}

The specimens examined by Lallemand $(1959,1963)$ and Fennah (1977), erroneously identified as $B$. collaris, were actually specimens of $B$. trilineata (Schmidt, 1926). 

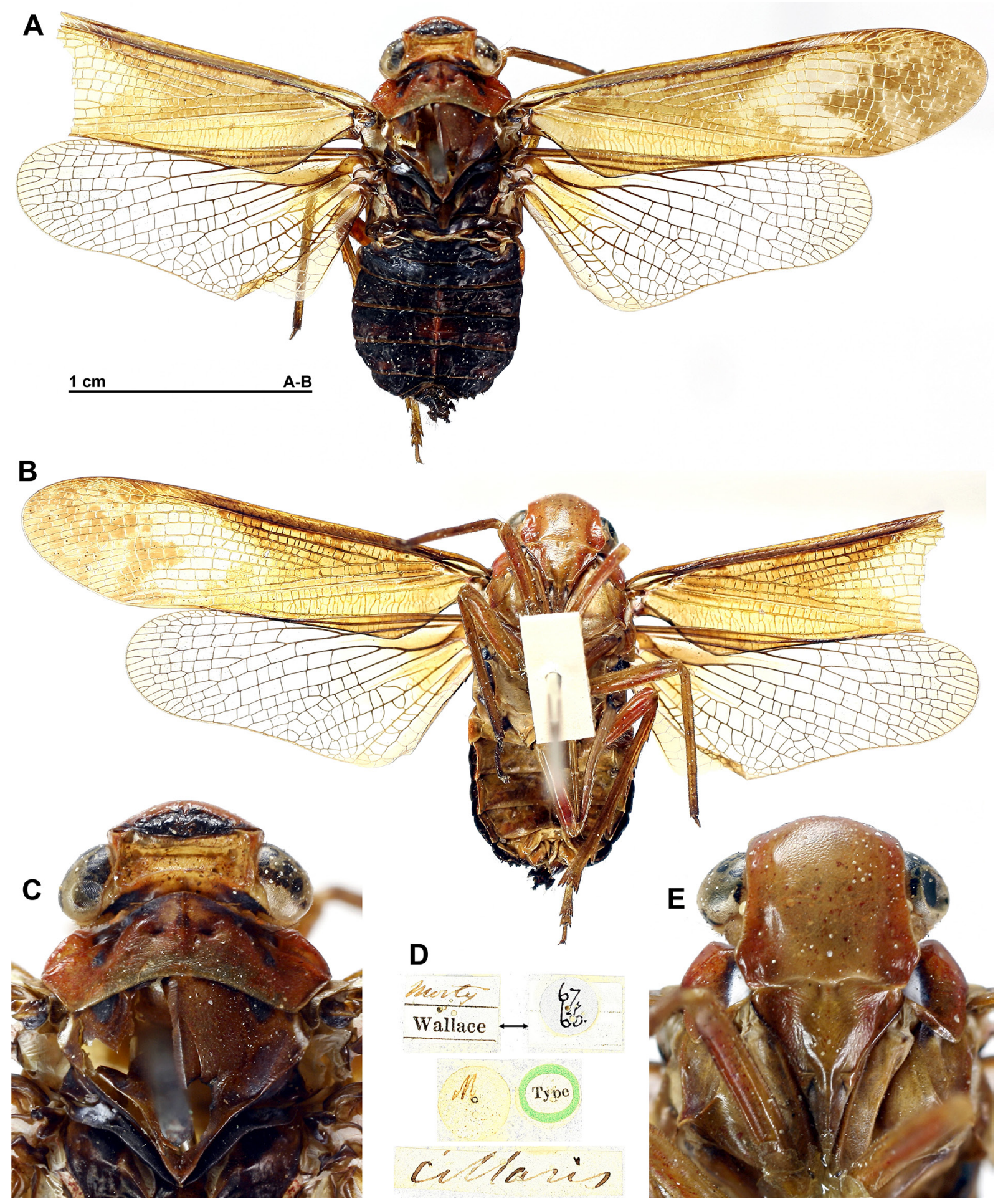

Fig. 4. Birdantis collaris (Walker, 1870), holotype, ․ A. Habitus, dorsal view. B. Habitus, ventral view. C. Head and thorax, dorsal view. D. Labels. E. Head, normal view of frons. C-E not to scale. 


\section{Diagnosis}

This species can be separated from all other species of Birdantis by the following combination of characters:

(1) frons entirely yellow-brown, without lines or spots (Fig. 4E)

(2) bulge between frons and vertex black (Fig. 4C)

(3) abdomen mostly black dorsally (Fig. 4A) and brown ventrally (Fig. 4B)

(4) tegmina opaque on basal half and infuscate on distal half (Fig. 4A)

(5) hind wings largely hyaline, with basal angle yellowish (Fig. 4A)

\section{Material examined}

\section{Holotype}

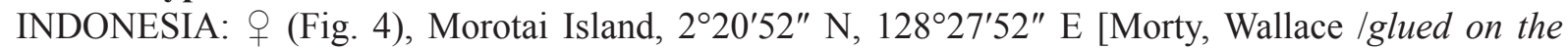
reverse: 67 66] [M] [Type] [collaris] [BMNH(E), \#651887] (BMNH).

\section{Distribution}

Morotai Island (holotype) and Halmahera Island (Breddin 1900) (Fig. 3).

\section{Birdantis decens Stål, 1863}

Figs 3, 5

Birdantis decens Stål, 1863: 581 (described; compared with Neotropical genus Poiocera de Laporte, 1832), 582 (compared with B. delibuta Stål, 1863).

Birdantis decens - Walker 1870: 100 (listed). - Kirkaldy 1913: 11 (compared with a specimen tentatively attributed to B. delibuta). — Metcalf 1947: 92 (catalogued). — Lallemand 1959: 194 (keyed), 195 (B. similis (Schmidt, 1911) possible junior synonym of B. decens (error!)); 1963: 10 (keyed). Fennah 1977: 376 (keyed), figs 3-4 (male genitalia). — Nagai \& Porion 1996: 14 (listed).

\section{Diagnosis}

This species can be separated from all other species of Birdantis by the following combination of characters:

(1) frons yellowish, with five longitudinal black lines not reaching ventral margin of frons, the three central ones merging together dorsally in a transverse line and central one dilated in middle (Fig. 5F)

(2) bulge between frons and vertex coloured as vertex (Fig. 5C)

(3) abdomen mostly black dorsally (Fig. 5A) and brown ventrally (Fig. 5B)

(4) tegmina opaque on basal half and hyaline on distal half (Fig. 5A)

(5) hind wings largely hyaline, with basal angle red (Fig. 5A)

\section{Material examined}

\section{Holotype}

INDONESIA: $\widehat{\partial}$ (Fig. 5), Aru Island, $6^{\circ} 07^{\prime} 14^{\prime \prime}$ S, $134^{\circ} 30^{\prime} 00^{\prime \prime} \mathrm{E}$ [Aru Isl /on the reverse: 5848 ] [Birdantis]

[Type] [Birdantis decens Stål] [BMNH(E), \#651892] (BMNH).

\section{Distribution}

Aru Island (Fig. 3). 


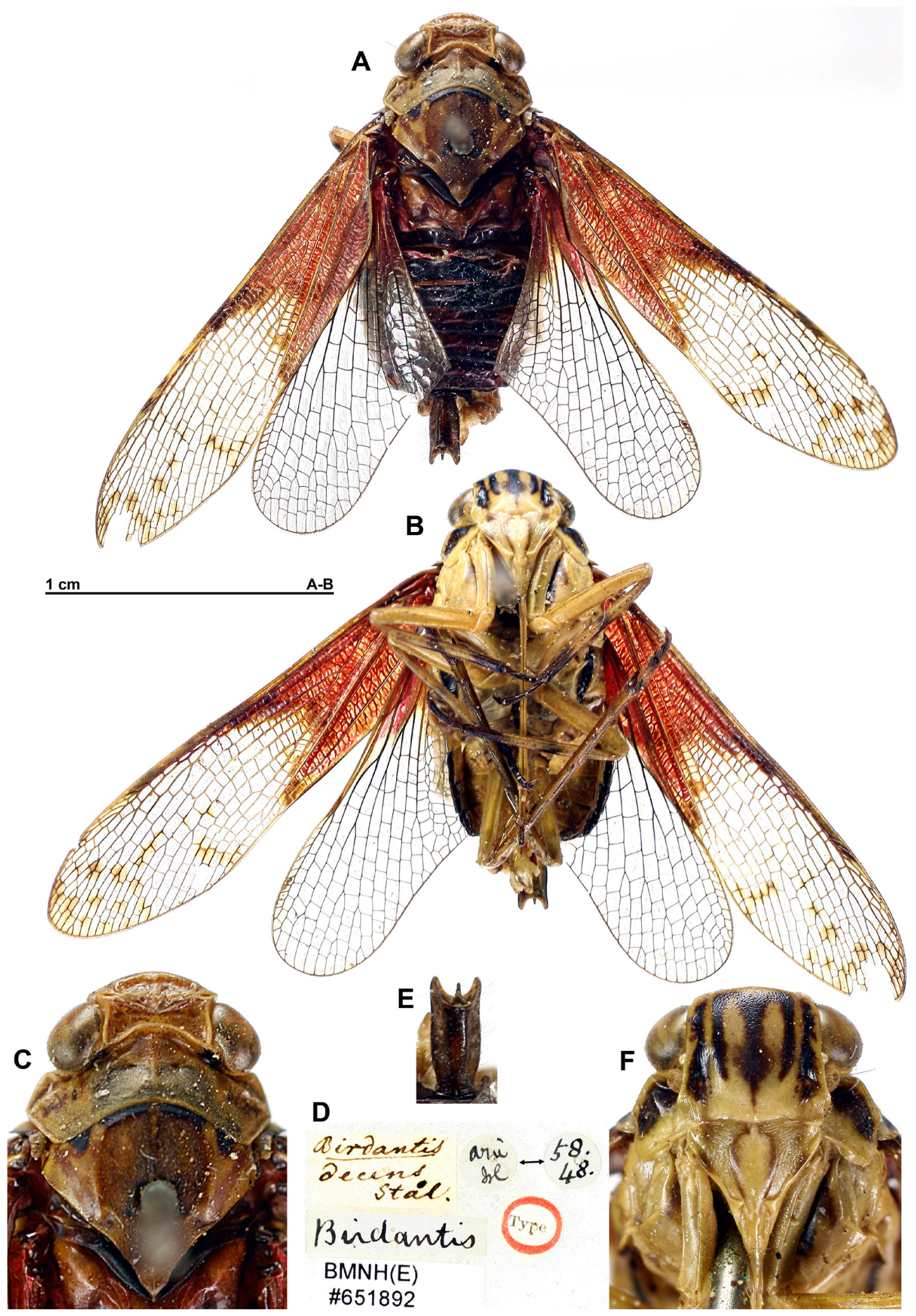

Fig. 5. Birdantis decens Stål, 1863, holotype, $\hat{\jmath}$. A. Habitus, dorsal view. B. Habitus, ventral view. C. Head and thorax, dorsal view. D. Labels. E. Anal tube, dorsal view. F. Head, normal view of frons. $\mathrm{C}-\mathrm{F}$ not to scale. 


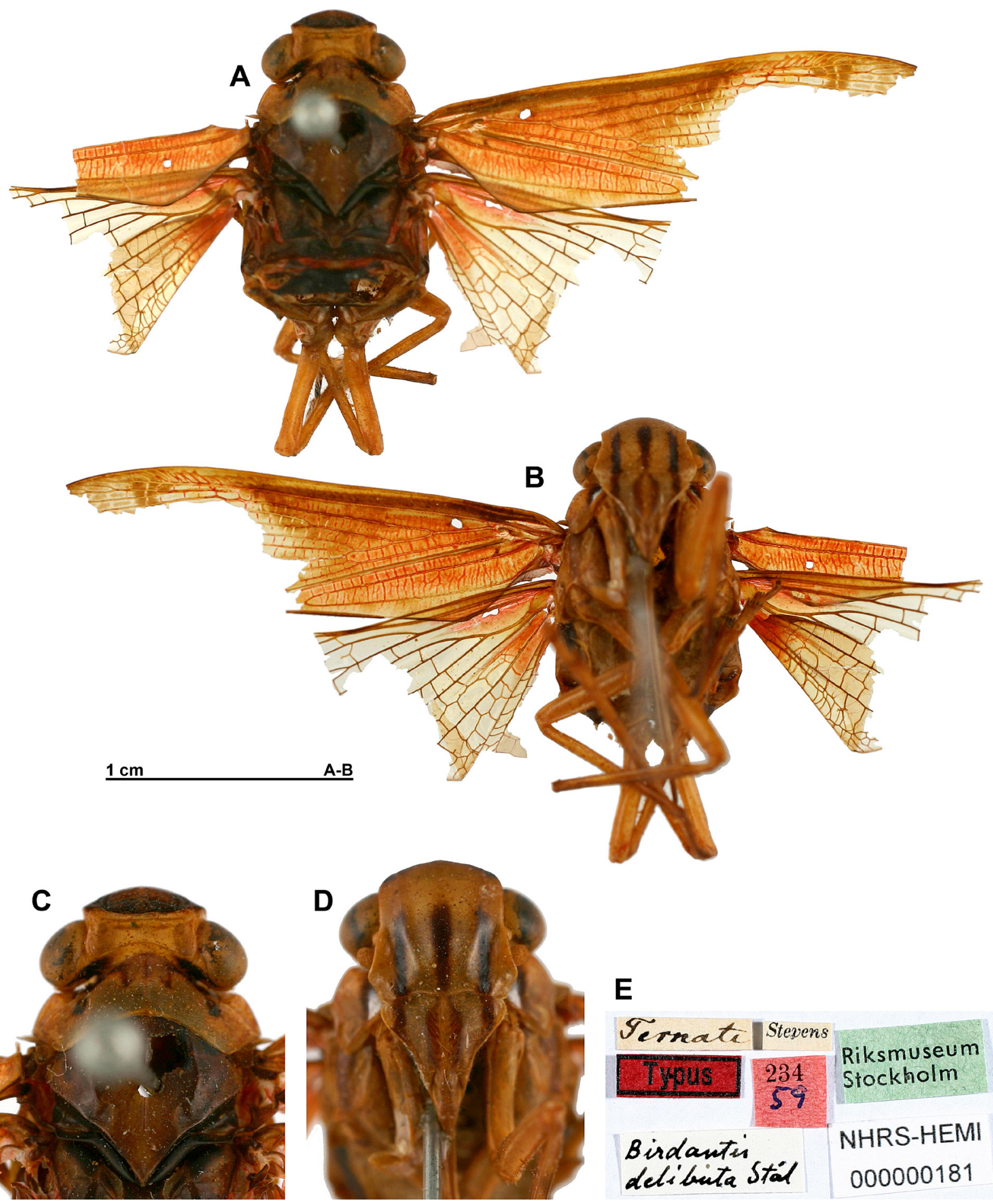

Fig. 6. Birdantis delibuta Stål, 1863, holotype. A. Habitus, dorsal view. B. Habitus, ventral view. C. Head and thorax, dorsal view. D. Head, normal view of frons. E. Labels. C-E not to scale. 
Birdantis delibuta Stål, 1863

Figs 3,6

Birdantis delibuta Stål, 1863: 582 (described; compared with B. decens Stål, 1863).

Birdantis delibuta - Metcalf 1947: 92 (catalogued). — Lallemand 1959: 194 (keyed; senior synonym of B. trilineata (Schmidt, 1926) (error!); recorded from Buru and Ambon Islands (errors!)); 1963: 11 (same as preceding reference). — Fennah 1977: 376 (keyed, listed). — Nagai \& Porion 1996: 14 (catalogued).

non Birdantis delibuta - Kirkaldy 1913: 11 (tentative attribution of an immature specimen from Ambon Island to B. delibuta). — Fennah 1977: fig. 7 (anal tube). — Nagai \& Porion 1996: pl. 3, fig. 56 (habitus).

\section{Note}

The specimen mentioned by Kirkaldy (1913) as well as those illustrated by Fennah (1977) and Nagai \& Porion (1996), erroneously identified as B. delibuta, were actually specimens of B. trilineata (Schmidt, 1926).

\section{Diagnosis}

This species can be separated from all other species of Birdantis by the following combination of characters:

(1) frons yellow-brown with three dark brown lines limited dorsally to level of middle of eyes, and with the two lateral ones extending on to clypeus (Fig. 6B)

(2) bulge between frons and vertex dark brown and vertex yellow-brown (Fig. 6C)

(3) tegmina opaque on basal half and infuscate on distal half (Fig. 6A)

(4) hind wings largely smoky, with a basal red marking (Fig. 6A)

(5) anterior margin of frons in dorsal view rounded but not strongly protruding (Fig. 6C)

\section{Material examined}

\section{Holotype}

INDONESIA: abdomen lost (Fig. 6), Ternate Island, $0^{\circ} 48^{\prime} 07^{\prime \prime} \mathrm{N}, 127^{\circ} 20^{\prime} 41^{\prime \prime} \mathrm{E}$ [Ternate] [Stevens] [234, 59] [Birdantis delibuta Stål] [Riksmuseum Stockholm] [NHRS-HEMI 000000181] (NHRS).

\section{Distribution}

Ternate Island (Fig. 3).

Birdantis trilineata (Schmidt, 1926) stat. rev. Figs 3, 7-9

Myrilla trilineata Schmidt, 1926: 228 (described).

Myrilla trilineata - Metcalf 1947: 84 (catalogued).

Birdantis delibuta - Lallemand 1963: 11 (treated as a junior synonym of B. delibuta (error!)). - Fennah 1977: fig. 7 (anal tube (of a specimen of B. trilineata erroneously attributed to B. delibuta!)). Nagai \& Porion 1996: 14 (treated as a junior synonym of $B$. delibuta (error!)), pl. 3, fig. 56 (habitus (specimen of $B$. trilineata from Ambon Island erroneously attributed to B. delibuta!)). 

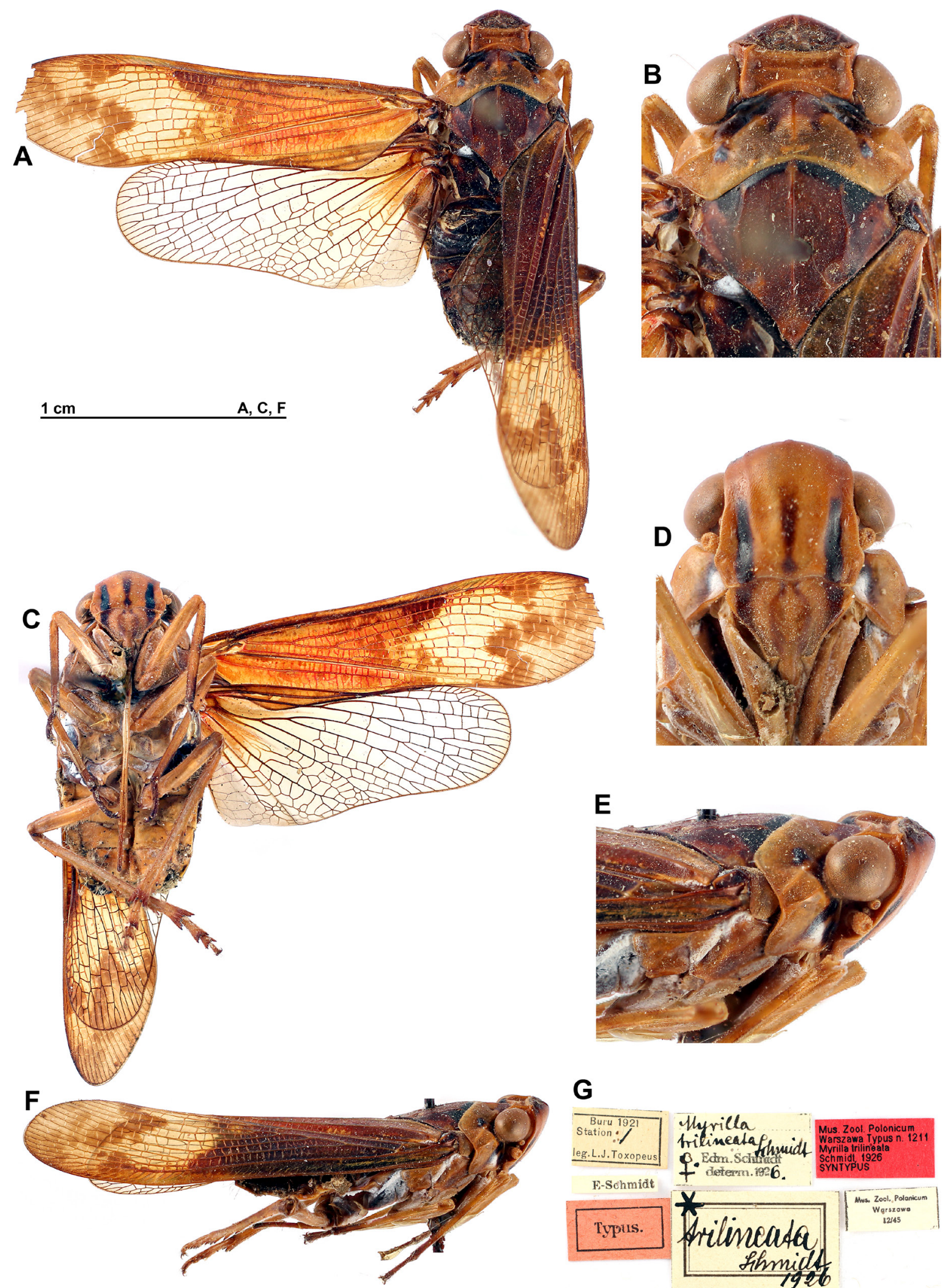

\section{E}

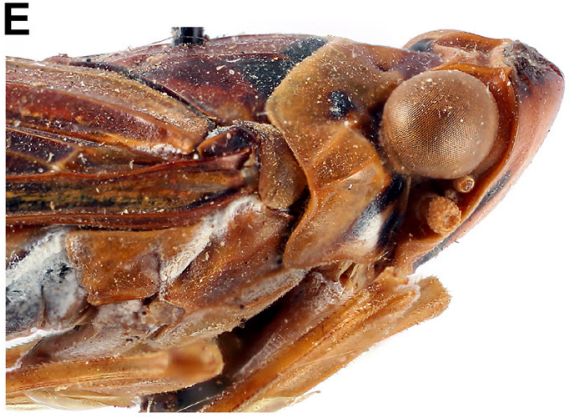

\section{G}

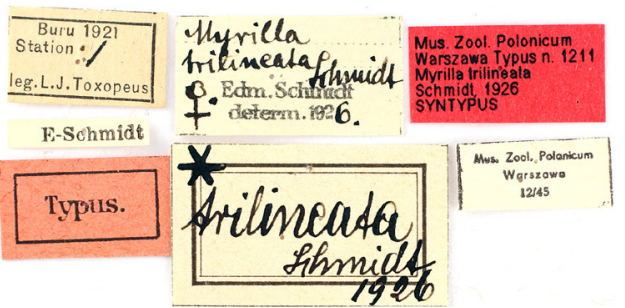

Fig. 7. Birdantis trilineata (Schmidt, 1926), lectotype, . . A. Habitus, dorsal view. B. Head and thorax, dorsal view. C. Habitus, ventral view. D. Head, normal view of frons. E. Head and thorax, lateral view. F. Habitus, lateral view. G. Labels. B, D, E not to scale. 


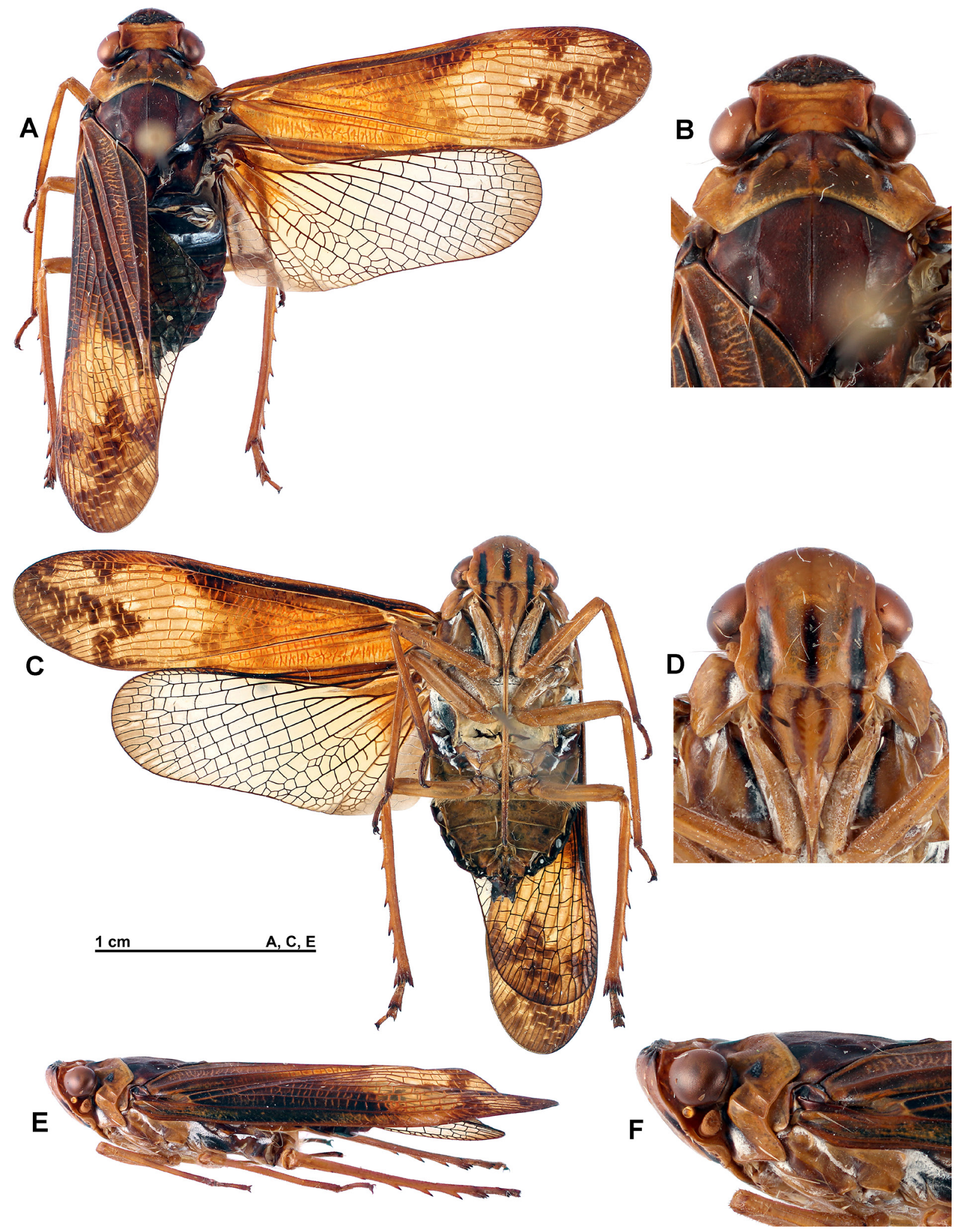

Fig. 8. Birdantis trilineata (Schmidt, 1926), + , Boano Island. A. Habitus, dorsal view. B. Head and thorax, dorsal view. C. Habitus, ventral view. D. Head, normal view of frons. E. Habitus, lateral view. F. Head and thorax, lateral view. B, D, F not to scale. 


\section{Diagnosis}

This species can be separated from all other species of Birdantis by the following combination of characters:

(1) frons yellow-brown, with three black-brown lines limited dorsally to level of middle of eyes, and with the two lateral ones extending on clypeus (Figs 7D, 8D)

(2) bulge between frons and vertex dark brown and vertex yellow-brown (Figs 7B, 8B)

(3) tegmina opaque on basal half and infuscate on distal half (Figs 7A, 8A)

(4) hind wings largely smoky, with a basal reddish brown marking (Figs 7A, 8A)

(5) abdomen mostly dark red dorsally (Figs 7A, 8A) and yellow-brown ventrally (Figs 7C, 8C)

(6) anterior margin of frons in dorsal view rounded and strongly protruding (Figs 7B, 8B)

\section{Material examined}

\section{Lectotype}

INDONESIA: $q$ (designated to improve nomenclatural stability in the group, Fig. 7), Buru Island, $3^{\circ} 23^{\prime} 55^{\prime \prime}$ S, 12638'54" E [Buru 1921, Station: 1 leg. L.J. Toxopeus] [E. Schmidt] [Typus] [Myrilla trilineata Schmidt , , Edm. Schmidt determ. 1926.] [*trilineata Schmidt 1926] [Mus. Zool. Polonicum Warszawa Typus n. 1211 Myrilla trilineata Schmidt, 1926 Syntypus] [Mus. Zool. Polonicum Warszawa 12/45] (ZMPA).

\section{Paralectotype}

INDONESIA: , , Buru Island, same collection data as for lectotype (ZMPA).

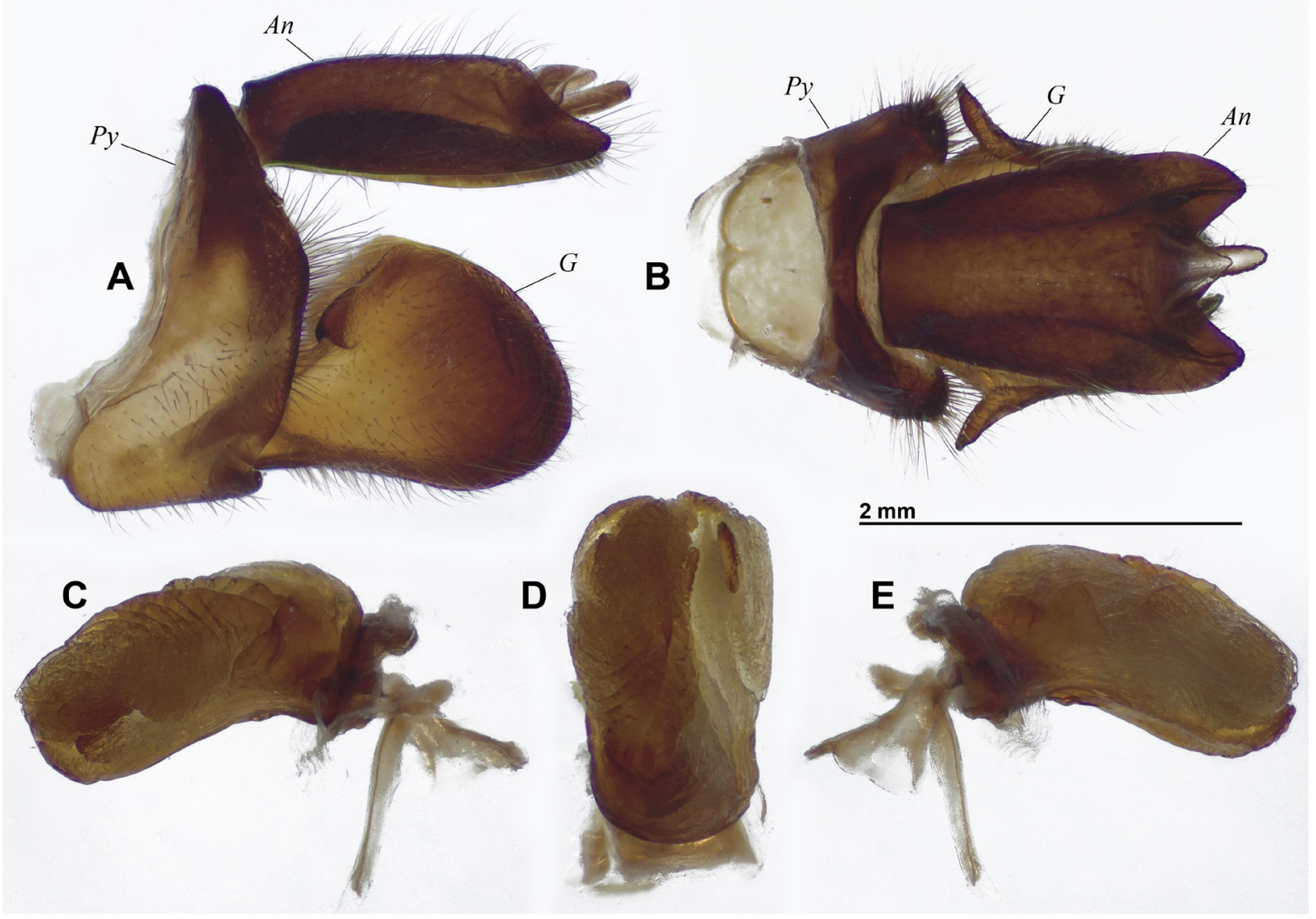

Fig. 9. Birdantis trilineata (Schmidt, 1926), ô, genitalia. A. Pygofer, anal tube and gonostyli, left lateral view. B. Pygofer, anal tube and gonostyli, dorsal view. C. Aedeagus, right lateral view. D. Aedeagus, dorsal view. E. Aedeagus, left lateral view. Abbreviations: $A n=$ anal tube; $G=$ gonostyli; $P y=$ pygofer. 


\section{Other material}

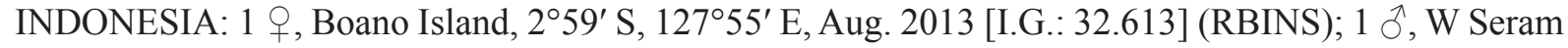

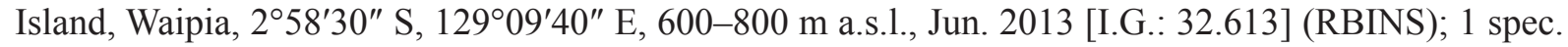
(abdomen lost; "vittiventris" Walker, in litt.), Ambon Island, $3^{\circ} 38^{\prime} \mathrm{S}, 128^{\circ} 07^{\prime} \mathrm{E}$, Wallace leg. (BMNH).

\section{Supplementary description}

\section{Male genitalia}

Pygofer higher than long, about 2.0 times as high as maximum length, longer ventrally and abruptly narrowing on dorsal $1 / 2$ in lateral view; dorsal margin of pygofer horizontal in lateral view (Fig. 9A). Anal tube elongate, about 1.5 times as long as maximum breadth, nearly straight with ventral margin sligtly curved in lateral view; progressively broadening from base towards $3 / 4$ of length in dorsal view, then with lateral margins converging; apical margin strongly, roundly emarginate in dorsal view, acutely rounded in lateral view (Fig. 9A-B). Gonostyli slightly elongate in lateral view, with ventral margin slightly concave and posterior margin broadly rounded; anterodorsal margin slightly emarginate after lateral process; lateral process laminate, curved laterally and apically pointed, with apical point directed lateroventrally (Fig. 9A-B). Aedeagus mostly membranous (Fig. 9C-F).

\section{Distribution}

Buru, Seram, Ambon and Boano Islands (Fig. 3).

\section{Discussion}

Together with the previous work on Australian species of Birdantis (Constant 2011), a large part of the genus has now been reviewed, although three species from Maluku are still only documented from their female type specimens, which were collected about 150 years ago.

The Papuan species were treated by Fennah (1977), but the conclusions of this work need to be assessed and refined by a thorough study of the type material of the species and their male genitalia, especially the taxa described by Schmidt $(1906,1907,1911)$ and Lallemand $(1959,1963)$, the types of which were not studied by Fennah.

The suprageneric position and the relationships with the other genera, notably the Oriental Gebenna and Polydictya and the Australian Desudaba and Desudaboides, will need further study, especially based on molecular data.

The biology of the species of Birdantis remains nearly completely undocumented in terms of development, phenology, host plants, behaviour etc., and the male genitalia still need to be described for several species.

\section{Acknowledgments}

I thank Mr Edy Bhaskara (Indonesia) for so kindly providing the material of the new species; $\mathrm{Mr}$ Tomasz Huflejt (ZMPA), Mrs Gunvi Lindberg (NHRS), and Mr Max Barclay and Mr Mick Webb $(\mathrm{BMNH})$ for their help with the material under their care; Miss Mado Berthet for her help in improving the genitalia plates; Prof. Thierry Bourgain (MNHN) and Prof. Murray J. Fletcher (Orange Agricultural Institute, Orange, NSW, Australia) for their valuable comments and suggestions. This study benefitted from funds of the European Union for a visit to the collection of BMNH (Synthesys Project - Grant GBTAF-1642) and to the collections of NHRS (Synthesys Project - Grant SE-TAF-527). 


\section{References}

Bourgoin T. 2018. FLOW (Fulgoromorpha Lists on The Web): A World Knowledge Base Dedicated to Fulgoromorpha. Ver. 8, updated (2 Jan. 2018).

Available from https://www.hemiptera-databases.org/flow/

Bourgoin T., Wang R.R., Asche M., Hoch H., Soulier-Perkins A., Stroinski A., Yap S. \& Szwedo J. 2015. From micropterism to hyperpterism: recognition strategy and standardized homology-driven terminology of the fore wing venation patterns in planthoppers (Hemiptera: Fulgoromorpha). Zoomorphology 134 (1): 63-77. https://doi.org/10.1007/s00435-014-0243-6

Breddin G. 1900. Hemiptera gesammelt von Professor Kükenthal im Malayischen Archipel. Abhandlungen der Senckenbergischen naturforschenden Gesellschaft 25: 139-202. Available from https://biodiversitylibrary.org/page/25232372 [accessed 3 Aug. 2018].

Constant J. 2004. Révision des Eurybrachidae (I). Le genre Amychodes Karsch, 1895 (Homoptera: Fulgoromorpha: Eurybrachidae). Bulletin de l'Institut royal des Sciences naturelles de Belgique 74: $11-28$.

Constant J. 2010. A new species of Polydictya from Lombok (Hemiptera, Fulgoromorpha, Fulgoridae). Nouvelle Revue d'Entomologie 26 (2): 155-161. [Is this the correct reference? Cited in Remarks on Birdantis, but not included in the list of references in the manuscript.]

Constant J. 2011. The genus Birdantis Stål in Australia (Hemiptera: Fulgoromorpha: Fulgoridae). Zootaxa 2885: 44-54.

Constant J. 2015. Review of the effusus group of the lanternfly genus Pyrops Spinola, 1839, with one new species and notes on trophobiosis (Hemiptera: Fulgoromorpha: Fulgoridae). European Journal of Taxonomy 128: 1-23. https://doi.org/10.5852/ejt.2015.128

Distant W.L. 1888. An enumeration of the Rhynchota received from Baron von Müller, and collected by Mr. Sayer in New Guinea during Mr. Cuthbertson's expedition. Transactions of the Entomological Society of London 1888: 475-489. Available from https://biodiversitylibrary.org/page/14677470 [accessed 3 Aug. 2018].

Distant W.L. 1906. Rhynchotal notes.-XXXVIII. Annals and Magazine of Natural History, Series 7 18: 18-32. Available from https://biodiversitylibrary.org/page/51222672 [accessed 3 Aug. 2018].

Fennah R.G. 1977. New species and new records of Fulgoridae (Homoptera: Fulgoroidea) from New Guinea. Pacific Insects 17 (4): 373-403.

Gerstaecker C.E.A. 1895. Ueber einige bemerkenswerthe Fulgorinen der Greifswalder zoologischen Sammlung. Mittheilungen des Naturwissenschaftlichen Vereines für Neu-Vorpommern und Rügen 27: $1-50$.

Kirkaldy G.W. 1913. On some new species of leafhoppers. Part 1. Bulletin of the Experiment Station of the Hawaiian Sugar Planters' Association, Division of Entomology 12: 7-27. Available from https://biodiversitylibrary.org/page/15500765 [accessed 3 Aug. 2018].

Lallemand V. 1959. Etude des Fulgorides de la Nouvelle Guinée (Rhynchota, Homoptera). Nova Guinea, New Series 10 (2): 187-196.

Lallemand V. 1963. Révision des Fulgoridae (Homoptera). Deuxième partie. Faunes asiatique et australienne. Mémoires de l'Institut royal des Sciences naturelles de Belgique, 2e Série 75: 1-99.

Metcalf Z.P. 1947. Part 9. Fulgoridae. In: Metcalf Z.P. 1954 (ed.) General Catalogue of the Homoptera. Fascicule IV. North Carolina State College, Raleigh, NC. 
Monk K.A., De Fretes Y. \& Reksodiharjo-Lilley G. 1997. The Ecology of Nusa Tenggara and Maluku. Periplus Press, Singapore.

Nagai S. \& Porion T. 1996. Fulgoridae 2: Catalogue illustré des faunes asiatique et australienne. Sciences Nat, Compiègne, France.

Naskrecki P. \& Nishida K. 2007. Novel trophobiotic interactions in lantern bugs (Insecta: Auchenorrhyncha: Fulgoridae). Journal of Natural History 41 (37-40): 2397-2402.

https://doi.org/10.1080/00222930701633570

O’Brien L.B. 2002. The wild wonderful world of Fulgoromorpha. Denisia 4: 83-102.

Schmidt E. 1906. Beitrag zur Kenntnis der Fulgoriden. Entomologische Zeitung, herausgegeben von dem entomologischen Vereine zu Stettin 67: 183-213. Available from

https://biodiversitylibrary.org/page/25554004 [accessed 3 Aug. 2018].

Schmidt E. 1907. Beitrag zur Kenntnis der Fulgoriden. Die Arten des Genus Myrilla Distant. Entomologische Zeitung, herausgegeben von dem entomologischen Vereine zu Stettin 68: 113-116. Available from https://biodiversitylibrary.org/page/9011434 [accessed 3 Aug. 2018].

Schmidt E. 1911. Neue Fulgoriden. Zoologischer Anzeiger 38: 161-171. Available from https://biodiversitylibrary.org/page/30153420 [accessed 3 Aug. 2018].

Schmidt E. 1926. Fauna Buruana. Homoptera. Treubia 7 (3): 217-258.

Shorthouse D.P. 2010. SimpleMappr, an online tool to produce publication-quality point maps. Available from http://www.simplemappr.net [accessed Jan. 13, 2018].

Stål C. 1863. Hemipterorum exoticorum generum et specierum nonnullarum novarum descriptiones. Transactions of the Entomological Society of London, Series 3 1: 571-603. Available from https://biodiversitylibrary.org/page/32121525 [accessed 3 Aug. 2018].

Urban J. \& Cryan J. 2009. Entomologically famous, evolutionarily unexplored: the first phylogeny of the lanternfly family Fulgoridae (Insecta: Hemiptera: Fulgoroidea). Molecular Phylogenetics and Evolution 50: 471-484. https://doi.org/10.1016/j.ympev.2008.12.004

Walker F. 1870. Catalogue of the homopterous insects collected in the Indian Archipelago by Mr. A.R. Wallace, with descriptions of new species. Zoological Journal of the Linnean Society 10: 82-193. Available from https://biodiversitylibrary.org/page/31587958 [accessed 3 Aug. 2018].

Manuscript received: 21 April 2018

Manuscript accepted: 25 June 2018

Published on: 18 September 2018

Topic editor: Gavin Broad

Desk editor: Danny Eibye-Jacobsen

Printed versions of all papers are also deposited in the libraries of the institutes that are members of the EJT consortium: Muséum national d'Histoire naturelle, Paris, France; Botanic Garden Meise, Belgium; Royal Museum for Central Africa, Tervuren, Belgium; Natural History Museum, London, United Kingdom; Royal Belgian Institute of Natural Sciences, Brussels, Belgium; Natural History Museum of Denmark, Copenhagen, Denmark; Naturalis Biodiversity Center, Leiden, the Netherlands; Museo Nacional de Ciencias Naturales-CSIC, Madrid, Spain; Real Jardín Botánico de Madrid CSIC, Spain; Zoological Research Museum Alexander Koenig, Bonn, Germany. 